\title{
Author Correction: Heritability estimates for 361 blood metabolites across 40 genome-wide association studies
}

Fiona A. Hagenbeek, René Pool (1D, Jenny van Dongen (1D, H.M. Draisma, Jouke Jan Hottenga, Gonneke Willemsen, Abdel Abdellaoui, Iryna O. Fedko, Anouk den Braber (D), Pieter Jelle Visser (D), Eco J.C.N. de Geus (D), Ko Willems van Dijk (D), Aswin Verhoeven (D), H. Eka Suchiman (D, Marian Beekman (D), P. Eline Slagboom (D), Cornelia M. van Duijn, BBMRI Metabolomics Consortium, Amy C. Harms (D),

Thomas Hankemeier, Meike Bartels (1), Michel G. Nivard (1) \& Dorret I. Boomsma (1)

Correction to: Nature Communications https://doi.org/10.1038/s41467-019-13770-6, published online 7 January 2020.

The original version of the Supplementary Information associated with this Article included an incorrect Supplementary Data 1 file, in which additional delimiters were included in the first column for a number of rows, resulting in column shifts for some of these rows. The HTML has been updated to include a corrected version of Supplementary Data 1; the original incorrect version of Supplementary Data 1 can be found as Supplementary Information associated with this Correction.

In addition, the original version of this Article contained an error in the author affiliations. An affiliation of Abdel Abdellaoui with Department of Psychiatry, Amsterdam UMC, University of Amsterdam, Amsterdam, The Netherlands was inadvertently omitted. This has now been corrected in both the PDF and HTML versions of the Article.

\footnotetext{
Open Access This article is licensed under a Creative Commons Attribution 4.0 International License, which permits use, sharing, adaptation, distribution and reproduction in any medium or format, as long as you give appropriate credit to the original author(s) and the source, provide a link to the Creative Commons license, and indicate if changes were made. The images or other third party material in this article are included in the article's Creative Commons license, unless indicated otherwise in a credit line to the material. If material is not included in the article's Creative Commons license and your intended use is not permitted by statutory regulation or exceeds the permitted use, you will need to obtain permission directly from the copyright holder. To view a copy of this license, visit http://creativecommons.org/licenses/by/4.0/.
}

(C) The Author(s) 2020 